\title{
The Use of Computer Simulation in Cooperative Learning to Minimize Students' Misconceptions of Momentum and Impulse
}

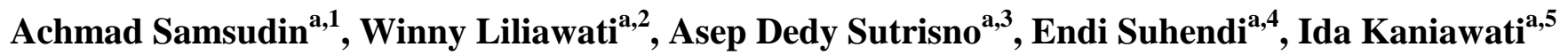 \\ ${ }^{a}$ Department of Physics Education FPMIPA, Indonesia University of Education (UPI), Jl. Dr. Setiabudhi No. 229, Bandung \\ 40154, Indonesia \\ 1.
}

\begin{abstract}
Momentum and impulse are two of the most abstract concepts that exist in physics, especially mechanics. Momentum and impulse are difficult to be learned by implementing conventional learning. Almost students have difficulties in learning momentum and impulse. These difficulties lead to students' misconceptions on this concept. The aim of this research was to determine the profile of students' misconceptions on the momentum and impulse concept by using computer simulations in cooperative learning. This research methodology was conducted in a quasi-experimental design with one group of pre-test and post-test for 37 students as research subjects. The data was collected by multiple choices providing with a scale Certainty of Response Index (CRI). The study results showed that the profile of students' misconceptions on momentum and impulse was more than $20 \%$ in a high school in the city of Bandung.
\end{abstract}

Index Terms- computer simulations, misconceptions, momentum and impulse

\section{Introduction}

Physics is one of the compulsory subjects that must be mastered by students. As noted by Ref. [1] that "Physics is the most fundamental science that was instrumental in the development of science and technology". One of the most important concepts in physics is momentum and impulse. Momentum and impulse are two of the sub-topics in the mechanics. Concepts of momentum and impulse are abstract concepts. The concepts of momentum and impulse cannot be explained directly, due to the momentum and impulse cannot be observed. Therefore, it is necessary to find appropriate methods to deliver the concepts of momentum and impulse correctly.

Learning is a major gateway for students to acquire knowledge. The knowledge transfer occurs during the learning process takes place. During the learning process, students gain conceptions and misconceptions. Ref. [2] states that one of the main sources of difficulty in learning physics concepts is due to the occurrence of errors or misconceptions on students. Misconception by Hammer [2] can be viewed as "a conception or cognitive structure attached to a strong and stable in the minds of students who actually deviate from conception suggested by experts, which could mislead the students in understanding natural phenomena and conduct scientific explanation".

Many students have misconceptions on physics concepts, for example on the topic of momentum and impulse. Based on the results of a study conducted by Ref. [3], Gunes stated that a third of the 192 students were able to explain the concept of momentum correctly and less than $25 \%$, which explains the concept of impulse correctly. This shows that the concepts of momentum and impulse are elusive and misconceptions are very likely to happen. Therefore, appropriate learning methods can be used to minimize misconceptions [2].

A lot of studies have found that computer simulations obtained to minimize misconceptions. Ref. [2] explained that "computer simulations were one method that can help to change the concept, especially in minimizing misconceptions." Furthermore Ref. [2] states that "the use of computer simulation is very beneficial, because it can do itself many times over." Even the simulation should not be done at school or lab, but as long as the computer available anywhere. The use of this simulation was to reduce the many risks that often arise in the practical implementation in the laboratory as stated that "Multimedia simulation, however, is an additional method that is inexpensive to facilitate change in the concept" [3]. Thus users will more quickly understand the concepts that are being learned properly.

In their research, Ref. [4] said that "cooperative learning using computer simulations are effective in overcoming misconceptions mechanics conceived by high school students." Reference [1] said that learning cooperative is "working together to accomplish shared goals" or if it is defined cooperative learning is to work together to achieve a common goal. Therefore, cooperative learning is a learning that relies on the cooperation of a group directed by the teacher to make students accountable for learning. This allows the use of simulation in cooperative learning students to further reinforce concepts.

\section{Methods}

This study exerted a quasi-experimental research design using a one group pre-test and post-test. The study subjects were randomly selected in one of the high schools in the city of Bandung, West Java, Indonesia. The research sample selected was one class XI with 37 students. The use of 
learning models for these classes was computer simulationassisted cooperative learning, and was given a pre-test and post-test.

The instrument was in the form of multiple choice questions with five answer options and used the scale of Certainty of Response Index (CRI) with a graduated scale of 0 until 5. CRI scale was used to determine whether there was a misconception that by looking at the answer choices of students who answered incorrectly selected but the CRI scale high. CRI was [5] explained briefly in Table 1.

Table 1 Provisions for Distinguishing between Know Concepts, misconceptions and Not Know Concepts for Individual Respondents

\begin{tabular}{|c|c|c|}
\hline $\begin{array}{c}\text { Answers' } \\
\text { Criteria }\end{array}$ & $\begin{array}{c}\text { Low CRI } \\
(<2,5)\end{array}$ & $\begin{array}{c}\text { High CRI } \\
(>2,5)\end{array}$ \\
\hline Correct & Answer correctly but \\
Answer & $\begin{array}{c}\text { Answer correctly but high } \\
\text { know the concept of } \\
\text { (Lucky guess) }\end{array}$ & $\begin{array}{c}\text { CRI means mastering the } \\
\text { concept well }\end{array}$ \\
\hline Incorrect & $\begin{array}{c}\text { Answer is wrong but } \\
\text { low CRI mean did not } \\
\text { know the concept of }\end{array}$ & $\begin{array}{c}\text { Answer is wrong but high } \\
\text { CRI means there is } \\
\end{array}$ \\
\hline
\end{tabular}

This instrument consisted of four essential concepts of momentum and impulse to the material that is the concept of momentum, impulse concepts, concept relations and impulse momentum, kinetic energy is based on the concept of momentum. This instrument has been judged by experts and has been tested in the early identification of misconceptions to class XII (Grade Twelve).

\section{Results and Discussion}

\section{A. Design of Simulation}

Simulations which were used in this research had been developed by constructing Flash MX. This multimedia has a lot of benefits which was needed by authors to minimize misconception in momentum and impulse. Flash $M X$ is one of attractive computer programs that was easy to be applied in simulating physics concept especially momentum and impulse. Then this program was able to make abstract conception to be more real conception so that students could be easier to comprehend all concepts. Simulations which were developed include collision of two objects in 1-D and 2-D, momentum and impulse of two cars such simulation in Fig. 1 (a) and (b).

Simulation was designed by using Flash $M X$ which supported into cooperative learning TSTS. All of simulation has characterization in minimizing misconception about momentum and impulse. This simulation was developed in four development areas (4-D), i.e. 1) defining, 2) planning, 3) developing and 4) disseminating. In defining phase, researchers have constructed simulation in story-board and program schema. Second step planning was preparing concept which were simulated to minimize the potential misconceptions for instance collision of two objects with vector illustration on Fig. 1. Third step was developing to design simulation of all concepts of momentum and impulse through multimedia Flash MX. Finally disseminating step was implementing simulation of momentum and impulse in collecting data about students' profile to decrease misconceptions.

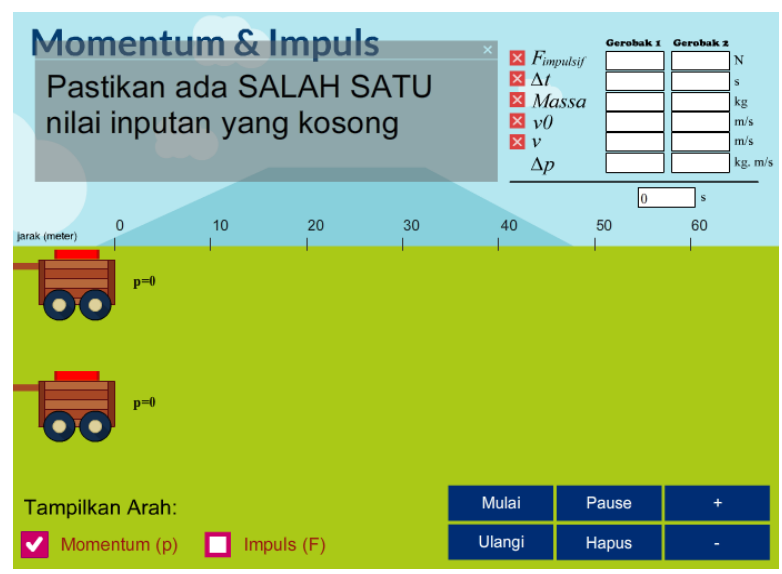

(a)

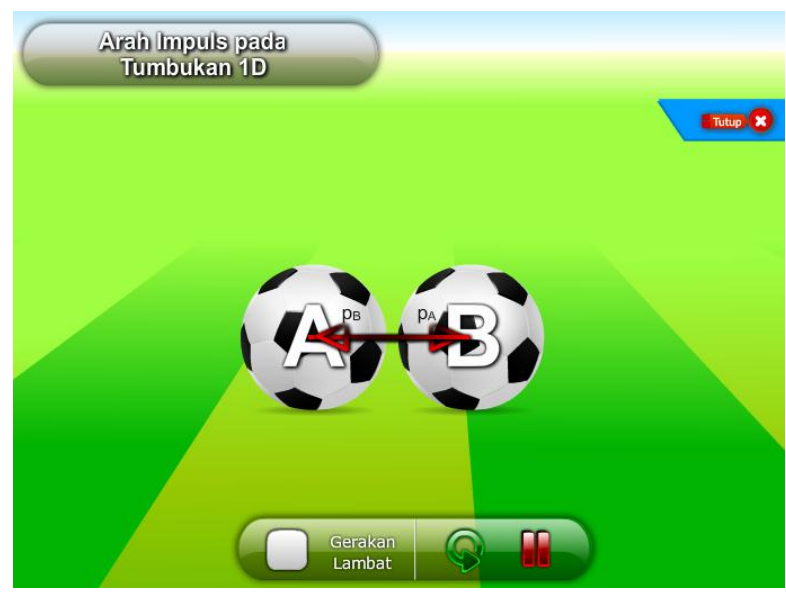

(b)

Fig. 1 (a) and (b) Simulations of 1-D Collision of Two Balls

All of simulations which have been developed were implemented in one classroom that has misconceptions problems. Students who have problems in misconceptions were selected by exerting diagnostic test. Researchers implemented this simulation to gain potential profile of momentum and impulse conception. Not only computer simulation which was implemented in this classroom but also cooperative learning TSTS too. Computer simulation was integrated by cooperative learning to minimize misconceptions in momentum and impulse.

\section{B. Profile of Misconceptions}

A profile of misconceptions was obtained from the initial identification (pre-test instrument), and post-test results for each class. It can be briefly shown as given in Fig. 2. The profile of misconceptions both students of class XII and XI who have learned a matter of momentum and impulse still exists. The difference in teaching has also showed differences in the profile of the misconceptions. In addition to cooperative methods, students were not given the opportunity to freely express ideas (preconceptions) that students have so that the students cannot correct about the truth of the concept that they received. They also did not 
have a chance to straighten out if it was the wrong concept. It is showed that the profile of misconceptions for classical class earn a percentage above $40 \%$, however it is showed that the percentage of misconceptions for post-test results of the experimental class was the smallest $(21.3 \%)$. It means that the learning in the experimental classroom was better in minimizing misconceptions than control classroom. In line with Ref. [6] stated that computer simulation could significantly decrease misconceptions for students who learn physics concepts. It is seen that the percentage of correct understanding of the concept of a class of students in experimental high of $70.6 \%$.

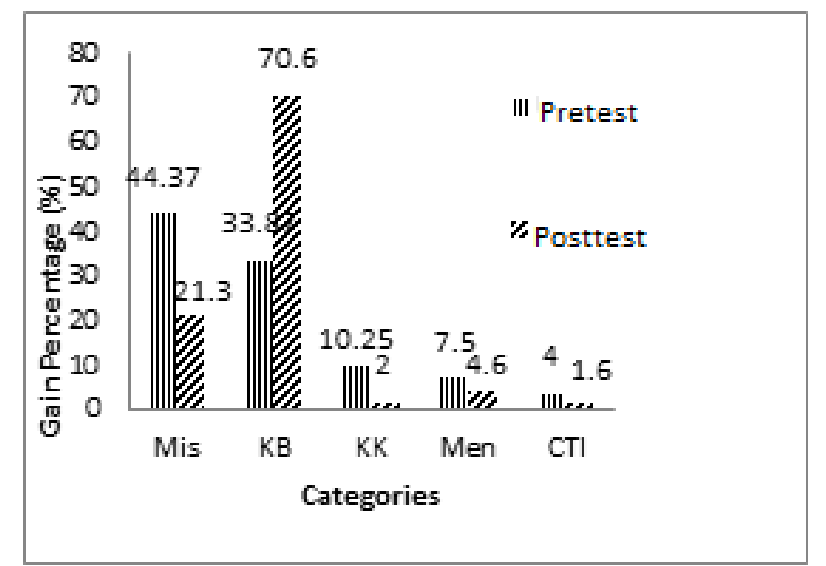

Notes: Mis $=$ Misconceptions, $K B=$ Correct Concept, $K K=$ do not know concept, Men $=$ Guess, $C T I=C R I$ is not filled

Fig. 2 Mean of Momentum and Impulse Concept Achievement.

If it is seen from the comparison of the results of the pre-test and post-test students before and after the cooperative learning using computer simulations, noticeable decrease in percentage of misconceptions as shown in Fig. 3.

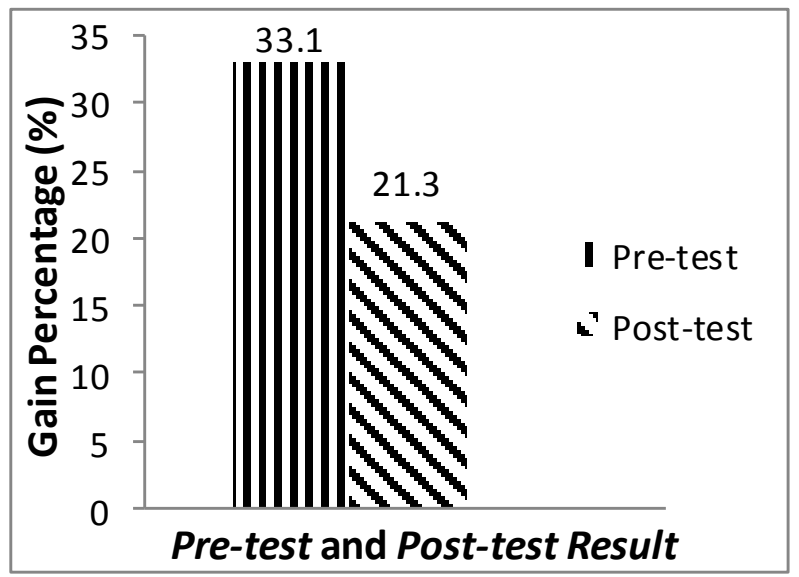

Fig. 3 Percentage of Decreasing Misconceptions.

Based on Fig. 3, it shows a decrease of misconceptions in the experimental class after using a model of cooperative learning with computer-aided simulation. In the pre-test results misconceptions percentage of $33.1 \%$, while the posttest results of the percentage gain of $21.3 \%$. This shows that there is a decrease in the percentage of misconceptions around 10\%. Reference [7] said "misconception-based multimedia are, of course, not the whole answer to conceptual change." This statement means that students who were less active cannot undergo conceptual change. This would have an impact on students' misconceptions that could potentially experience. A percentage of misconceptions in the experimental class would be minimized if students were more active during learning. Because of the form of cooperative learning, the students were required to be active in the group respectively. Hence, learning by implementing computer-assisted simulation in cooperative learning model was to minimize misconceptions also in improving the mastering of the concept.

\section{Conclusion}

Based on the research and discussion that has been done, it could be concluded that the use of computer simulation in cooperative learning model was potential to minimize misconceptions students on the concept of momentum and impulse.

\section{Acknowledgments}

Authors thank research teams of using computer simulation to minimize physics conceptions at Physics Education Department, FPMIPA, Indonesia University of Education (UPI).

\section{References}

[1] A. Isliyanti and R. Kurniadi, "Pembuatan kumpulan pembahasan miskonsepsi pada beberapa topik materi mekanika”. Prosiding Simposium Nasional Inovasi Pembelajaran dan Sains, Bandung, pp. 144-147, 2011.

[2] P. Suparno, Miskonsepsi \& Perubahan Konsep dalam Pendidikan Fisika. Jakarta: Grasindo, 2013.

[3] D. A. Muller and M. D. Shamar, "Tackling Misconceptions in Introductory Physics using Multimedia Presentations", Proceedings of the Science Teaching and Learning Research Including Threshold Concepts Symposium, Sidney: UniServe Science Teaching and Learning Research Proceedings, pp. 58-63, 2007.

[4] S. Saehana and Haeruddin, Pengembangan Simulasi Komputer Dalam Model Pembelajaran Kooperatif Untuk Meminimalisir Miskonsepsi Fisika Pada Siswa SMA Di Kota Palu. Prosiding Pertemuan Ilmiah XXV HFI Jateng \& DIY, (pp. 286-290), 2012.

[5] Y. R. Tayubi, Identifikasi Miskonsepsi Pada Konsep-Konsep Fisika Menggunakan Certainty of Response Index (CRI), Universitas Pendidikan Indonesia, Pendidikan Fisika. Bandung: Mimbar Pendidikan, 2005.

[6] M. Huda, Cooperatif Learning, Metode Teknik Struktur dan Model Penerapan. Yogyakarta: Pustaka Pelajar, 2013.

[7] A. G. Sekercioglu and M. S. Kocakula, "Grade 10 Students' misconception about impulse and momentum". Journal of Turkish Science Education, vol 5, no. 2, pp. 47-59, 2008. 